$\underline{\text { articles }}$

\title{
Why Small Deals Don't Get Done: Evidence From Rural Entrepreneurs
}

\author{
Jeff Stambaugh ${ }^{1}$, Andy $\mathrm{Yu}^{2}$ b \\ 1 Dillard College of Business, Midwestern State University, ${ }^{2}$ College of Business and Economics, University of Wisconsin-Whitewater \\ Keywords: Deal Failure, Valuation, Economic Development \\ https://doi.org/10.53703/001c.29482
}

\section{Journal of Small Business Strategy}

Vol. 31, Issue 4, 2021

\begin{abstract}
For myriad reasons, rural entrepreneurs may want to harvest by selling their business. While these entrepreneurs may look for inspiration to larger, public deals, there are few relevant insights to glean from these deals. Despite the high stakes involved for rural entrepreneurs and potential buyers, researchers have placed little attention on dealmaking at the lower end of the spectrum. We address this lack of research by answering the research question: Why do deals involving small companies go unconsummated? Because research on why large deals fall through is sparse and of limited applicability, we ground our research using insights from the venture financing arena (venture capitalists and angel investors) about why deals between entrepreneurs and investors do not close successfully. Applying a novel dataset from an economic development effort in a small southwestern U.S. city, we analyze the reasons why an investor group investigated 20 potential small deals, but none eventually closed. We found that issues both with the potential buyers and sellers led to the deal failures, with issues involving the valuation and also the selling entrepreneur being the most common deal-breakers. Furthermore, through this investigation, we gained insights into the challenges of an investor-driven model for economic development.
\end{abstract}

\section{Introduction}

Rural entrepreneurs launch businesses that can allow them to prosper financially beyond their non-entrepreneurial neighbors (L. Yu \& Artz, 2019). But after successfully growing a business or perhaps nearing retirement age, rural entrepreneurs may look to harvest by selling their business. These entrepreneurs can look for inspiration to some big deals involving urban entrepreneurs like John Mackey, who eventually sold Whole Foods to Amazon for \$13.7 billion, or Amnon Shashua and the sale of his Jerusalem-based startup called Mobileye to Intel for $\$ 15.3$ billion. These deals can generate incredible wealth for founders and reshape entire markets and industries. Accordingly, academic researchers have thoroughly investigated issues regarding large mergers and acquisitions such as: the economic rationale (e.g., Kim \& Singal, 1993; Wang \& Zajac, 2007), environmental factors (e.g., Thornton, 2001); firm characteristics that motivate deals (e.g., Baum et al., 2000; Graebner \& Eisenhardt, 2004); and the various performance outcomes (e.g., Cannella \& Hambrick, 1993; P. Wright et al., 2002).

While these large deals may inspire rural entrepreneurs, there are perhaps few relevant insights to glean from the big deals. Rural entrepreneurs' deals may reshape local economies, but they do not reshape industries. They do not involve investment banks or boards of directors. Still, even if the transaction price is meager by corporate standards, the economic stakes may be enormous for rural entrepreneurs and prospective buyers. Selling the business may represent the single largest monetary transaction of a lifetime and may cap decades of work. Unfortunately, researchers have placed little attention to deals at the lower end of the spectrum. Specifically, there are few insights in the literature regarding why smaller firms like those created by rural entrepreneurs do not successfully change hands (Ahlers et al., 2016; Bruce \& Picard, 2006; Scholes et al., 2007). Family business research, which includes both large and small deals, has identified that more should be known about the process and outcomes of divestment efforts (King et al., forthcoming; Worek, 2017).

We seek to address this lack of research by answering the research question: Why do deals (a term we use to signify a transaction involving a change of ownership) involving small companies go unconsummated, which should apply to the rural ecosystem? In contrast to large M\&A deals, where most announced deals do close (e.g., Chakrabarti \&

\footnotetext{
a 3410 Taft Blvd, Wichita Falls, TX 76308, USA, (940) 397-6343, jeff.stambaugh@msutexas.edu Corresponding Author

b 800 West Main Street, Whitewater, WI 53190, USA, (262) 472-7035, yua@uww.edu
} 
Mitchell, 2016), most attempts to close a transaction involving small firms fail (e.g., Anderson et al., 2007). Given that the vast majority of firms are small and that a failure to successfully find a buyer often results in firm liquidation (Leroy et al., 2015), we suggest a study of why potential deals do not get done is particularly important. Because research on why large deals fall through is limited (Chakrabarti \& Mitchell, 2016; Shen \& Reuer, 2005) and of limited applicability (Wong \& O’Sullivan, 2001), we ground our research using insights from the startup financing arena (venture capitalists and angel investors) about why deals between entrepreneurs and investors do not close successfully.

Accordingly, the paper first develops the potential market for small deals and addresses the potential applicability of research into why large deals go unconsummated. The paper then builds on insights from venture and angel capital investments, particularly research into why deals do not occur. Applying a novel dataset from an economic development effort in a small southwestern U.S. city, we employ a case-study approach structured by past empirical research to analyze the reasons why an investor group investigated 20 potential small deals, but none eventually closed. We found that issues both with the potential buyers and sellers led to the deal failures and also gained insights into a type of economic development.

\section{Literature Review}

This lack of insight on why smaller firms do not successfully change hands is not due to a dearth of smaller deals. According to data from the Institute for Mergers, Acquisitions and Alliances (IMAA), there were almost 16,000 M\&As in North America in 2019. Only 47 deals worldwide had a transaction value of greater than $\$ 1$ billion, so most deals are not at the top of the market. Furthermore, the IMAA data are based on publicly announced deals, so many small business sales probably are not reflected in these numbers. Companies with sales below $\$ 150$ million are labeled as the "lower middle-market" (Slee, 2009). In terms of revenue and company size, the vast majority of firms fall into the lower middle market's very bottom tier. NAICS Association data indicates that only 19 percent of firms with annual revenue of over $\$ 1$ million have annual revenues of more than $\$ 10$ million. That suggests that 81 percent of the "million-dollar firms" have annual revenues of less than $\$ 10$ million. Similarly, U.S. Census data indicate that, among firms with more than five employees, 71 percent of those firms have 19 employees or less. These numbers suggest that the large majority of potential M\&A deals involve companies with annual revenue of less than $\$ 10$ million and/or fewer than 20 employees.

Not only is the small business universe large, but it is also filled with businesses that are considering a sale. A 2014 PricewaterhouseCooper (PwC) survey indicated that 20 percent of family businesses were contemplating a sale (Leibell, 2015). As only 12 percent of family businesses make it to the third generation, there are many sales (or failures) of these businesses in the first and second generation. Furthermore, the business owner's approaching retirement (Dawson \& Barrédy, 2018) and the inability to find a feasible successor within a family (De Massis et al., 2008) are triggers for a sale. The aging of the baby boomer generation suggests the opportunity for M\&As among small firms is already strong and should stay that way for a while.

While the potential may be high, actual dealmaking among these smaller firms is fraught with false starts and failures. In one survey, private equity firms indicated that only 16 percent of the Letters of Intent (LOI) signed with a prospective seller, which stipulated the terms of a possible sale, led to a completed sale (Anderson et al., 2007). One director of a middle-market investment banking firm likened the M\&A business to hunting: "Sometimes you bag big game-but more often than not, the target runs away unharmed" (Slee, 2009: 13). Actually, the target may run away, but it may not be unharmed. Leroy and colleagues (Leroy et al., 2015) found that 62 percent of entrepreneurs who attempted to sell their business ended up liquidating the business instead, missing out on the financial and emotional benefits of a successful deal.

Extant research into why larger deals do not happen is limited (Chakrabarti \& Mitchell, 2016; Shen \& Reuer, 2005; Wong \& O'Sullivan, 2001). In part, this may be because the vast majority of announced deals among larger, public companies do close. For example, Wong \& O’Sullivan (2001) found that 95 percent of friendly takeover bids succeeded, and even around 50 percent of hostile takeover bids succeeded. Other research found that three-quarters of domestic and two-thirds of cross-border proposed tie-ups closed (Chakrabarti \& Mitchell, 2016). For the smaller number of deals that did not close, the main reasons included geography (too distant) and deal type (hostile and/or too unrelated) (Muehlfeld et al., 2012). Even these limited findings may not be too applicable to small deals due to the significantly higher levels of information asymmetry in small versus large deals (Anderson et al., 2007; Moore Jr et al., 1995; Wong \& O’Sullivan, 2001).

\section{Decision-making Processes for Small Deals: Insights From Venture Financing}

The decision-making processes used by Venture Capitalists (VCs) and Business Angels (BAs) to invest in young companies could be informative for decisions surrounding the purchase of more mature companies. Private equity (PE) companies, which are primarily known for purchasing larger mature businesses, use the same decision processes as do VCs and BAs when they are investing (Dawson, 2011), including screening, due diligence, and negotiations. PE investors use heuristics to make decisions, as do BAs and VCs (Harrison et al., 2015; Petty \& Gruber, 2011; Sinyard et al., 2020). The deal closure rates for VCs, BAs and PEs are also similar. Investing in startups and mature companies entails screening many possible candidates, with potential investors eliminating approximately 70 percent of the candidates at the first stage. The promising survivors of the first screen then undergo a more in-depth investigation, with only a small percentage of successful deals emerging from the process (Anderson et al., 2007; Mason et al., 2017; M. Wright et al., 2009). The BA population, who are primarily successful business owners, are also the same people who might consider purchasing an existing business (or 
investing in another individual trying to enter the ranks of the business owner). Although purchasing an existing business removes some of the risk associated with startups, there is still considerable risk involved as purchasers often plan to expand and innovate in the current business, significantly growing profitability in the process (Dawson \& Barrédy, 2018; Scholes et al., 2007). Accordingly, buyers and investors are evaluating the venture's growth and profitability potential in both startups and mature businesses.

Researchers have studied VC and BA decision-making for four decades (see Petty \& Gruber, 2011 for a summary of VC research and Maxwell et al., 2011 for BAs). A recent shift in focus from why deals do close to why deals do not successfully close is particularly helpful for investigating business sales by rural entrepreneurs. Maxwell and colleagues (2011) found that BAs use an "elimination-by-aspects" approach to deal evaluation, particularly when initially screening deals. This means potential investors search for reasons to say no rather than reasons to say yes. Petty \& Gruber (2011) used this same elimination-by-aspects approach to study VC decision-making. Using an initial framework of four categories for reasons to say no (product, market, team, and financial), the study used a qualitative approach to derive a grid of categories and sub-categories for why VCs did not consummate a deal with the entrepreneurs. Carpentier \& Suret (2015) used Petty and Gruber's (2011) grid as a starting point to investigate why BAs reject deals. We employ those findings to ground this study of why prospective deals are not consummated for small businesses. Furthermore, we go beyond Petty \& Gruber (2011) and Carpentier \& Suret (2015), who assumed that, when investigating deals, evaluators' decisions were homogeneous. Instead, by analyzing the decision heterogeneity of the evaluators, which may contribute to deal-breakers, we may offer a more finegrained analysis.

VCs and BAs use multiple stages in the decision-making process. The first stage, most commonly called the prescreening stage, eliminates 60-70 percent of the proposed deals (e.g Croce et al., 2017; Mason et al., 2017; Petty \& Gruber, 2011). In BA groups, it is common for a hired staff member to conduct the pre-screening evaluations. Some BA groups use as many as five discrete stages after the initial screening (Carpentier \& Suret, 2015), while others suggest there are only one (Mason \& Botelho, 2016) or two additional stages (Croce et al., 2017). In general, the process is that BAs and VCs seek further information on the deals that pass pre-screening and ultimately focus on negotiating deals with fewer than 10 percent of the originally proposed deals.

\section{Why do VCs and BAs Reject Deals}

While there is consensus about the percentages of how many prospects make it through the various stages, there is less consensus about the reasons why BAs and VCs reject potential deals. Petty \& Gruber (2011) suggested that investors use heuristics mainly in the early stages of deal screening, while others found evidence, particularly among highly experienced investors, of heuristics usage later in the detailed evaluation of potential deals. These more experienced investors also focus on different criteria when eval- uating prospects than less experienced investors (Harrison et al., 2015). Some found the rejection reasons change as the prospects move through the stages (Croce et al., 2017), while others found little variation in why investors rejected deals at the various stages (Carpentier \& Suret, 2015). A longitudinal study found investors reject prospects based more on investor fit as they gain experience Petty \& Gruber (2011). Indeed, several studies indicated a lack of investor fit, which considers factors such as investment size, compatibility with the existing portfolio, and the investor's personal experience, is the leading reason $(\sim 30 \%)$ why investors reject certain deals (Croce et al., 2017; Harrison et al., 2015; Petty \& Gruber, 2011).

There has been less agreement about the importance of the entrepreneur(s) leading the venture. Petty \& Gruber (2011) found VCs reject only two percent of the prospects for the people involved, whereas Mason and colleagues (2017) found BAs cited the people involved as a reason to reject a prospect 69 percent of the time. Other studies pegged people as the reason for rejection about ten percent of the time (Croce et al., 2017; Harrison et al., 2015). Recent systematic reviews of the extant literature on the criteria investors use when evaluating deals (Ferrati \& Muffatto, 2021; Granz et al., 2020) indicate a rough balance in the importance of the entrepreneur(s) and the other aspects of the venture. Granz and colleagues (2020) found VCs tilted slightly more toward the financial aspects of the venture while BAs focused a bit more on the entrepreneur(s).

\section{Sample}

\section{Methodology}

This project's data arose from a novel economic development effort in a small southwestern city in the United States (MSA population of 150,000 ). The city had a long-standing, conventional business recruitment effort run by the local Chamber of Commerce to persuade larger companies to establish business operations in the city. A group of local business leaders formed an entity called the "Growth Fund" (G.F.) to purchase small manufacturing businesses, relocating some or all company operations to the G.F.'s home city as part of an economic development strategy. Thirty-five investors joined the G.F. and provided sufficient seed capital to fund operations for one year. Over that year, the G.F. screened dozens of businesses and gave serious attention to 20 small businesses (all but one of the businesses had less than 30 employees) as a potential acquisition. However, none of those potential deals came to fruition, which led to the group suspending operations after the first year. As we discuss later in the paper, several of the G.F. members retrospectively acknowledged they wished the G.F had continued beyond a year.

The G.F. operated as a hybrid between a traditional PE group focused on the lower middle market and a traditional angel group. As in most angel groups, each G.F. member made their own investment decisions. The G.F. did not have a pool of pre-raised capital to deploy. About half of the G.F.'s members also belonged to a local angel investment group, which used this same principle of having every investor responsible for their own decisions. Much as the managing partners do in a PE group, the G.F. hired a full- 
time executive director (E.D.) to source and screen potential deals. The E.D. was uniquely qualified, having fifteen years' experience as a CEO and business group leader for a PE company. During that tenure in PE, the E.D. participated in seven acquisitions, so he was well versed in the PE acquisition model. The G.F.'s focus was on small, product-oriented manufacturing companies. Like many PE groups, the G.F. desired companies with significant ownership and management stability, anticipating that such companies were ripe for cost reductions, managerial enhancements, and product innovations that would allow substantial profit growth after changing ownership (Dawson \& Barrédy, 2018). The G.F. had a six-member Executive Committee (E.C.), whose role was to work with the E.D. to vet potential deals before bringing them to the membership as a proposed acquisition. The E.C. had veterans of the banking, oil and gas, medical supply, restaurant, and real estate industries. The E.C. brought only one potential deal to the membership, and it did not receive sufficient interest to go forward. As we develop later, this lack of success had to do with both the potential buyers and the sellers

Of the twenty screened deals, nine involved rural businesses, six businesses were located in small cities (populations less than 200,000 and well separate from larger cities), and five were located in large cities or their suburbs. While the metropolitan businesses might have had access to greater resources, the companies were similar to the others in terms of size, sole or family ownership, and a desire to exit the business. As seen later, the reasons the deals did not succeed were also similar to the other companies. Table 1 has more details about the 20 companies.

\section{Data Collection and Analysis}

The 20 companies represented mini-cases that allowed the authors to access the qualitative insights from each deal. Using mini-cases as data sources is well-established in the entrepreneurship literature and have been used to examine issues such as entrepreneurial failure (e.g., Singh et al., 2015), venture strategy-making (Ott \& Eisenhardt, 2020), crowdfunding (Murray et al., 2020), and even how entrepreneurs name their ventures (Engel et al., 2020). Given the challenges of accessing decision-makers for these types of deals, it is common to rely on data from one group (Mason et al., 2019). The authors were able to incorporate taxonomies from earlier research into why VC and BA deals did not close, which provided a helpful start to code the interviews.

The E.D provided the authors with materials he had collected about each business. These materials provided limited background information about the companies but had no information about the E.C.'s decision-making processes or outcomes about the companies. One of the paper's authors attended the group session where the G.F. membership reviewed the only deal recommended by the E.C.. That gave the author significant insights into why the membership rejected that one company.

To gather detailed insights into why the E.C. rejected the other nineteen companies, the authors interviewed the group's E.D. and three members of the E.C.. These interviews offered "rich, empirical data, especially when the phenomenon of interest is highly episodic and infrequent" (Eisenhardt \& Graebner, 2007: 28). This contrasts with Petty and Gruber's (2011) and Carpentier and Suret's (2015) studies, which used archival information. Given the inductive nature of the research, the interview method seemed well suited to analyzing the twenty cases. To minimize concerns about bias, we followed Eisenhardt and Graebner's (2007) advice and used multiple, knowledgeable informants rather than relying on a single informant's recollection. The interview approach also represented a form of engaged scholarship (Bansal et al., 2018), as one of the authors assisted in establishing the G.F., infrequently consulted on G.F. matters, and routinely interacted with the E.D. and E.C. members about non-G.F. matters. The interviews took place two years after the G.F. ended. As would be expected, the E.D. had detailed recollections of each deal; the E.C. members had less detailed recollections. They were quick to acknowledge these gaps, which reduces concern about impression management biases (Eisenhardt \& Graebner, 2007).

The authors used the grid of rejection categories and sub-categories (Table 2) initially developed by Petty and Gruber (2011) and then refined by Carpentier \& Suret (2015) to code the interviews independently. With a modified Delphi approach (A. Yu et al., 2012), we employed three steps to generate our data for further analyses. The first step was to create a master data matrix for the next stage of data recording. One of the authors listened to the four interviewees' recollections and decided the main themes (e.g., company name, founded year, location, asking price, etc.). Second, the researchers independently listened to the four interviews to jot down the key points of these 20 possible deals. At the end of this second step, we did not find any additional themes for this matrix. That is, we were able to include all of the details we needed using the original set of main themes we derived. The third step was that we independently used the grid (Table 2) to record our judgments about the reasons the deal did not close. After comparing our codes, we found we had $99 \%$ of agreement on the coded categories; we then reconciled the very few remaining areas of disagreement. The reconciliation was simple because there was a remarkable agreement between the E.D. and E.C. members' views of why the deals did not close. We listened to the interviews and discussed the differences to reach a consensus. In some cases, the interviews suggested there were multiple reasons why the deal failed. In those cases, the authors determined which issue was the primary reason versus the secondary reason for the failure.

\section{Results}

Issues associated with the G.F.'s specific needs and expectations caused the group to walk away from 35 percent (seven of the twenty) of the deals. In one case, the G.F. was not interested in the product category, but in four cases, the firm could not easily relocate to the G.F.'s small city. The E.C. deemed another business as too small to be interesting. The G.F. rejected the last deal principally because the E.C. had decided the G.F. would not succeed and did not seriously consider the deal. 
Table 1. Summary of Screened Companies and Deal Failure Reason

\begin{tabular}{|c|c|c|c|c|}
\hline $\begin{array}{l}\text { Company } \\
\text { Pseudonym }\end{array}$ & Location & Company Summary & $\begin{array}{l}\text { Primary Reason } \\
\text { Deal Failed }\end{array}$ & $\begin{array}{l}\text { Secondary Reason } \\
\text { Deal Failed }\end{array}$ \\
\hline Ranch 1 & $\begin{array}{l}\text { Small } \\
\text { City }\end{array}$ & $\begin{array}{l}\text { Almost failed two years previous to G.F. interest, but currently stable. Owners just wanted to exit without losing more } \\
\text { money. Few competitors in the niche industry. }\end{array}$ & 340 & 125 \\
\hline Ranch 2 & Rural & $\begin{array}{l}\text { Asking price } 7 x \text { multiple of reported cash flow. No marketing but well-known and regarded business among its } \\
\text { customers. Leader in a small niche. }\end{array}$ & 340 & \\
\hline Tank 1 & Rural & $\begin{array}{l}\text { Founder owned and led with very little documentation, financial or otherwise. An industry leader in a niche market but } \\
\text { tied to a major national, cyclical market. }\end{array}$ & 340 & 555 \\
\hline Machine 1 & $\begin{array}{l}\text { Small } \\
\text { City }\end{array}$ & $\begin{array}{l}\text { Repaired / fabricated parts with a single industry focus. Owner / key employee personal relationships with customers } \\
\text { key to business's consistent revenue. }\end{array}$ & 440 & 514 \\
\hline Fab 1 & Metro & $\begin{array}{l}\text { Sales were declining due to the poor health of several key family members / workers. The owner was loyal to the } \\
\text { workforce and reluctant to see the business relocated. }\end{array}$ & 121 & 514 \\
\hline Machine 2 & Metro & $\begin{array}{l}\text { Strong financial performer with founder looking to exit while still young. Major multinational corporation accounted } \\
\text { for } 90 \% \text { of revenue. Relocation was problematic. }\end{array}$ & 514 & 110 \\
\hline Fab 2 & Rural & $\begin{array}{l}\text { Produced about } 10 \text { dies per year for average selling price of } \$ 150,000 \text {. Significant investments in land and facilities } \\
\text { made relocation financially difficult. }\end{array}$ & 514 & \\
\hline Transpo 1 & Rural & $\begin{array}{l}\text { Owner had already sold the business once but repurchased it after the previous buyer almost caused the business to } \\
\text { fail. The business was still off the previous peak. }\end{array}$ & 513 & 320 \\
\hline Fab 3 & Metro & $\begin{array}{l}\text { Current owner's relationships with relatively small clientele would be hard to replicate. Produced highly customized } \\
\text { solutions for specific industries. }\end{array}$ & 440 & \\
\hline Machine 3 & $\begin{array}{l}\text { Small } \\
\text { City }\end{array}$ & $\begin{array}{l}\text { One multinational corporation accounted for } 50 \% \text { of revenue. The seller wanted a signed LOI before opening books } \\
\text { and a fast-track due diligence process. }\end{array}$ & 340 & \\
\hline Service 1 & $\begin{array}{l}\text { Small } \\
\text { City }\end{array}$ & $\begin{array}{l}\text { The startup business was willing to locate in the desired location to secure funding. Referred to G.F. from area angel } \\
\text { investor group. }\end{array}$ & 460 & 320 \\
\hline Machine 4 & $\begin{array}{l}\text { Small } \\
\text { City }\end{array}$ & Company in slow decline. Co-owners not communicating well and had disparate objectives. & 340 & 600 \\
\hline Machine 5 & $\begin{array}{l}\text { Small } \\
\text { City }\end{array}$ & The company was a supplier to companies owned by G.F. members. The owner received a competing offer. & 552 & 430 \\
\hline Transpo 2 & Metro & $\begin{array}{l}\text { The company had significant intellectual property and had once ceased production due to manufacturing issues. } \\
\text { Essentially a startup. }\end{array}$ & 121 & 222 \\
\hline Transpo 3 & Metro & $\begin{array}{l}\text { The company had a large, international customer base selling aftermarket products that complement a well-known } \\
\text { brand. Manufacturing } 100 \% \text { out-sourced. }\end{array}$ & 511 & \\
\hline Ranch 3 & Rural & Nationwide customer base, to include utility companies. Aging founder looking for an exit but opposed to relocation. & 514 & \\
\hline Tank 2 & Rural & The company didn't have a single computer in the work location. No previous marketing; ample markets for expansion. & 450 & \\
\hline
\end{tabular}




\begin{tabular}{|l|c|l|c|c|}
\hline $\begin{array}{l}\text { Company } \\
\text { Pseudonym }\end{array}$ & Location & \multicolumn{1}{c|}{ Company Summary } & $\begin{array}{c}\text { Primary Reason } \\
\text { Deal Failed }\end{array}$ & $\begin{array}{c}\text { Secondary Reason } \\
\text { Deal Failed }\end{array}$ \\
\hline Service 2 & $\begin{array}{l}\text { Small } \\
\text { City }\end{array}$ & $\begin{array}{l}\text { A thriving company with the owner looking for new investors more so than new owners. Local operations would } \\
\text { merely be a satellite of main operations elsewhere in the state. }\end{array}$ & 514 \\
\hline Tank 3 & Rural & $\begin{array}{l}\text { The owner maintained he had rebuffed interest from private equity firms. Claiming \$3M in annual revenue with ample } \\
\text { growth prospects. }\end{array}$ & 340 \\
\hline Waste 1 & Rural & The deal emerged late in G.F's timeline and probably would have gotten much more interest had it been vetted earlier. & 560 \\
\hline
\end{tabular}

Companies are listed in the order of G.F. consideration.

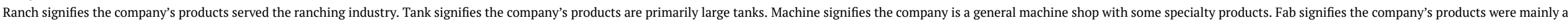
B2B fabrication business. Transpo signifies the company's products served the transportation market. Service signifies the company provided a specialized service. Waste signifies the company's products were in the waste management businesses. 
Twenty-five percent of the potential deals (five cases) failed because of disagreements over the firms' valuation. In two of the cases, these breakdowns occurred after substantial negotiations. In the other three cases, the gap between the entrepreneur's asking price and the E.C.'s estimate of an acceptable price was so large that the E.C. quickly decided the deal was not worth pursuing. The valuation was the secondary reason for three other deals. In one case, although the deal did not meet the G.F.'s criteria of relocating to its city, some investors in the G.F. might have done the deal anyway had the valuation been right.

Yet another 25 percent of the potential deals (five cases) failed to close because of concerns about the entrepreneur. The group walked away because it did not believe the entrepreneur(s) were trustworthy in two cases. In one case, the entrepreneurs (it was a team of two) were highly disorganized; the G.F. was not confident it could successfully fill in the gaps of procedures and knowledge post-purchase. Finally, in two cases, the G.F. felt the entrepreneur's knowledge and relationships with customers were so central to its success that the firms' performance would suffer without the entrepreneur.

The other three deals failed for a variety of reasons. In one case, another buyer bought the firm before the G.F. could act. In two cases, the G.F. judged the product had little hope of future success due to a lack of competitive differentiation. Our data also found that the "conflict between entrepreneurs" could also be the reason for a business to sell. We thus added this item to the grid modified from prior studies (Carpentier \& Suret, 2015; Petty \& Gruber, 2011). Table 2 has a summary of the deal failure reasons. The table also reveals that valuation (8 counts, $40 \%$ of the 20 cases) and out of investor focus-geography (6 counts, 30\% of the 20 cases) were the two main reasons why the small deals did not close in our study. The third reason had two counts for no USP (unique selling proposition)/competitive differentiation, key man issue, and integrity/ethics concerns.

\section{Discussion}

These results have at least five practical implications for rural entrepreneurs who aspire to sell their businesses. First, firm valuation is the most common deal breaker in our investigation of these small deals. Forty percent of the deals failed, at least partly, due to the sellers and potential buyers being too far apart on an agreed price or deal structure. For example, one family manufacturing firm founded by two brothers was the leading company in its niche market but wanted a very high price (i.e., seven times reported cash flow). The E.D. and E.C. thought this business had great potential and was a good fit for the G.F. Unfortunately, the deal did not close despite extensive G.F. efforts due to the big valuation difference between the G.F. and the family business owners. Astrachan \& Jaskiewicz (2008) proposed that family business owners usually factor emotional value into their business valuation on top of the financial value. Hence, in the family business owner's mind, the firm's total value is the sum of financial value plus emotional value. From this perspective, both the buyer and seller may consider the role emotional value plays in the negotiation process. While this value discrepancy is probably unsurpris- ing, it is a useful reminder to rural entrepreneurs who consider a business sale that they will likely have to accept a lower price than desired. Likewise, the buyer may also consider the small business owners' emotional value to reach an agreeable price.

Second, based on these results, rural entrepreneurs looking to exit should anticipate that it will be more challenging to find a buyer than it is for more urban entrepreneurs. While the G.F.'s criteria of finding re-locatable businesses may seem idiosyncratic, rural entrepreneurs may find a relatively smaller population of interested buyers unless the business can be relocated. Prospective rural entrepreneurs are often specific in location desires. It's not that they simply wish for a rural lifestyle; they wish to live in the community where they grew up and have family (L. Yu \& Artz, 2019). Hence, only prospective entrepreneurs in the business's immediate area may be interested in purchasing the company. Alternatively, the rural entrepreneur may have to confront the difficult decision to sell to a buyer who intends to relocate the business to their preferred area. Some potential sellers may refuse such opportunities out of allegiance to workers (one case for G.F.), allegiance to the community (one case for G.F.), or a strong desire to include real estate in the deal (one case for G.F.). Even if the rural entrepreneur is willing to allow relocation, the customer base or specific location advantages may preclude a relocation (two cases for G.F.).

A third practical implication is that there are many reasons why deals do not happen. Just as there are myriad reasons why BAs and VCs chose not to invest in startups (e.g. Croce et al., 2017; Harrison et al., 2015; Petty \& Gruber, 2011), there are myriad reasons beyond deal valuation and location why a rural entrepreneur's business does not sell easily. Perhaps most surprising to us is the number of deals derailed due to ethics concerns about the potential seller. But issues such as product category or the lack of a unique selling proposition also resulted in deal failures.

The fourth practical implication is that successful entrepreneurs with small businesses-rural and otherwise-have a paradox that the very elements of their competitive advantage may reduce their business value when it comes time to sell. In two cases, the G.F. concluded the business would suffer without the entrepreneur's detailed tacit knowledge of the business and extensive relationships with stakeholders. These entrepreneurs effectively differentiated their companies from their competitors and enjoyed a sustainable competitive advantage (Davidsson \& Honig, 2003). However, because one cannot easily transfer those elements of differentiation, much of the business value is not truly "for sale." Hence, to avoid selling their business at a steep discount, rural entrepreneurs have to build a supportive team that intentionally diminishes their personal contributions to the business before attempting to sell the business.

The final practical implication is about the socioemotional wealth (SEW) concerns of family businesses (GómezMejía et al., 2007). SEW is a family firm's affective endowment, indicating the family's attachment to and non-financial expectations for its business. Because family businesses are composed of family and business systems, each system has its goals, making family business a more complex organizational form (A. Yu et al., 2012). In the 20 
Table 2. Summary of Deal Failure Reasons

\begin{tabular}{|c|c|c|c|c|}
\hline & & & $\begin{array}{l}\text { Primary Reason Deal } \\
\text { Failed }\end{array}$ & $\begin{array}{l}\text { Secondary Reason Deal } \\
\text { Failed }\end{array}$ \\
\hline Category & Code & & & \\
\hline \multirow[t]{8}{*}{$\begin{array}{l}\text { Product and } \\
\text { Model }\end{array}$} & 110 & Strategy/model & & 1 \\
\hline & 121 & $\begin{array}{l}\text { No USP/competitive } \\
\text { differentiation }\end{array}$ & 2 & \\
\hline & 122 & Not convincing/compelling & & \\
\hline & 123 & Need proof of concept & & \\
\hline & 124 & Single product & & \\
\hline & 125 & Too basic & & 1 \\
\hline & 126 & Complexity & & \\
\hline & 130 & IP related & & \\
\hline \multirow[t]{7}{*}{ Market } & 210 & Existence/clarity & & \\
\hline & 221 & Too small or niche & & \\
\hline & 222 & Too crowded/competitive & & 1 \\
\hline & 223 & Too fragmented & & \\
\hline & 224 & Too large/mature & & \\
\hline & 230 & Acceptance/potential & & \\
\hline & 240 & Regulations & & \\
\hline \multirow[t]{4}{*}{ Financial } & 310 & Exit & & \\
\hline & 320 & Revenue/return potential & & 2 \\
\hline & 330 & Use of proceeds & & \\
\hline & 340 & Valuation & 5 & 3 \\
\hline \multirow[t]{7}{*}{ Team } & 410 & Experience & & \\
\hline & 420 & Reputation & & \\
\hline & 430 & Lack of confidence & & 1 \\
\hline & 440 & Key man issue & 2 & \\
\hline & 450 & No/incomplete management & 1 & \\
\hline & 460 & Integrity/ethics & 2 & \\
\hline & 470 & Asymmetry/distance & & \\
\hline \multirow[t]{13}{*}{$\begin{array}{l}\text { Investor } \\
\text { Specific }\end{array}$} & 511 & $\begin{array}{l}\text { Out of investor focus (OIF)-- } \\
\text { Product }\end{array}$ & 1 & \\
\hline & 512 & OIF-Stage & & \\
\hline & 513 & OIF-Size & 1 & \\
\hline & 514 & OIF-geography & 4 & 2 \\
\hline & 515 & Just not a G.F. deal & & \\
\hline & 521 & Competes with existing portfolio & & \\
\hline & 522 & $\begin{array}{l}\text { Not appropriate for portfolio at } \\
\text { this time }\end{array}$ & & \\
\hline & 523 & Too early for fund & & \\
\hline & 524 & No funds for region & & \\
\hline & 525 & $\begin{array}{l}\text { No time due to fund related } \\
\text { activities }\end{array}$ & 1 & \\
\hline & 530 & External source did not endorse & & \\
\hline & 541 & Need lead investor & & \\
\hline & 542 & Oversubscribed & & \\
\hline
\end{tabular}




\begin{tabular}{|l|l|l|l|l|}
\hline & & & $\begin{array}{l}\text { Primary Reason Deal } \\
\text { Failed }\end{array}$ & $\begin{array}{l}\text { Secondary Reason Deal } \\
\text { Failed }\end{array}$ \\
\hline & 543 & Existing investor interest & & \\
\hline & 544 & Lack of other investors & & \\
\hline & 551 & No response & & 1 \\
\hline & 552 & Deal closed by other investors & & \\
\hline & 553 & Not invited to participate & & \\
\hline & 554 & Terms rejected & & 1 \\
\hline Other & 555 & Decided not to sell at all & & 1 \\
\hline
\end{tabular}

cases, six cases (30\%) were family firms, but they did not prioritize a succession plan over selling the business. The E.D. considered family businesses an ideal target to acquire since family firms are more long-term oriented (Lumpkin et al., 2010) and more likely to fit the criteria of the G.F. A possible reason behind such an impression is that a family's name is on the business, so the family has to protect its reputation and identity to preserve SEW. Among these six family firms, four had challenges allowing a relocation, demonstrating that family entrepreneurs are very community-oriented. For example, one of the family owners was very loyal to employees and viewed them as family. Such a family mindset helps a family firm create trust, stewardship, and competitive advantages but makes it harder to sell the business.

\section{Deal and Group Epilogue}

The authors are aware of subsequent events in a few of the deals. The G.F. missed one deal because another buyer purchased the business before the G.F. could act. That proved to be fortuitous, as that machining business failed during a deep industry downturn. One of the deals the G.F. pursued most aggressively but ultimately could not close due to disagreements over valuation eventually sold several years later. The authors, unfortunately, do not have any information about the sales price. Finally, the G.F. rejected one deal as being too small. After the G.F. ceased operations, the E.D. bought that business with the blessing of the E.C. Instead of relocating the business, he chose to relocate to the business's rural location. The E.D. has improved marketing, implemented product enhancements, and streamlined processes such that annual revenue and profit have soared without growing the workforce. It can be argued that it was precisely the type of business the G.F. wanted.

This idea of local investors banding together to support economic development seems logical yet did not work satisfactorily in this situation. Through the interviews, we gained insights into the challenges associated with this version of economic development. From the beginning, the G.F. struggled with the twin priorities of investor return and economic development. While the priorities are not mutually exclusive, some deals appeared more promising for economic development, and other deals appeared to offer greater investor returns. In two cases, the G.F. continued due diligence on deals that could not relocate to the host city (and thus would not offer economic development benefits) because the E.C. thought the deals might offer strong investor returns. Had the investors proceeded with those deals, it would have reduced the capital available for economic development deals. In retrospect, the interviewees wished the group had exercised more patience, judging that one year was too optimistic to expect a solid first deal. Finding that solid first deal is important for an economic strategy because an excellent first acquisition can serve as the parent company for subsequent deals. One interviewee wished the G.F. had completed one of the machine shop deals, even if that deal was not particularly appealing, so it could have served as a parent for some smaller deals. Several interviewees commented that the distributed nature of the decision-making meant no one emerged as a "champion" for any deals. They wished someone would have gotten behind one or a few deals and pushed harder. In this aspect, the group perhaps needed to operate more like a traditional PE group and less like an angel group.

The G.F. experience did set the stage for subsequent major investment. About a year after the G.F. ceased operations, several members became aware of the opportunity-working with a small PE group not located in the region-to purchase a 250-employee manufacturing company and relocate some or all its operations to the host city. This deal did go forward, with former G.F. members investing several million dollars to make the purchase. Unfortunately, the deal became a case study about the risks of turning around a distressed business. After an aborted attempt at a partial relocation and significant cash infusions to cover continuing losses, the local investors took a total loss on the deal after a bankruptcy sale.

We add to the literature in several ways. First, our study is one of the first to explore small deal acquisitions to our knowledge. We respond to Carpentier \& Suret's (2015: 819) call to pay attention to small deals. Our cases provide some initial evidence showing why small deals are difficult to close and reveal the reasons behind the scene. Second, emerging from our data, "conflict between entrepreneurs" is another possible reason to sell a small business. We added this item to the grid developed by Petty \& Gruber (2011) and Carpentier \& Suret (2015). Future research may modify our grid to conduct similar studies in economic development or small deals. Third, over the coding process, we found the E.D. and the other three members of the E.C. were the primary decision-makers to decide if a deal should be moved 
forward. Notably, we suggest the heterogeneity of the deal evaluators may be an important factor in dealmaking. In both Petty and Gruber's (2011) and Carpentier and Suret's (2015) data analyses, they consistently assumed the homogeneity of deal decisions. We consider the relationship between the deal evaluation/evaluators and deal closing as an interesting research opportunity worthy of further probing. Finally, we provide insights into a novel economic development effort, particularly the inherent tension between investor and economic development goals. Our research may provide some thoughts for those businesses, institutions, or policymakers to make plans and provide incentives or grants.

Inevitably, our research entails several important limitations. First, our data are not longitudinal. Although we had some more information after the cessation of G.F. on a few cases, we did not have enough information to pursue a more long-term study. It would be helpful to see, for example, if the G.F.'s evaluation of those firms' valuation was reasonable. In doing so, buyers and sellers may learn a better approach to developing reasonable offers. Second, as with Petty \& Gruber (2011) and Carpentier and Suret (2015), our research is qualitative. We thus do not have enough sample size to test the relationship between two or three variables. Future research may build on our findings by deploying our updated grid to a larger number of respondents via a survey. Questions future researchers might ask include: How does the heterogeneity of investment evaluators' background affect the decision-making process and results? What are those essential factors contributing to the difference in firm valuation between a buyer and seller? Compared to nonfamily businesses, do family firms expect a higher price? If yes/no, why? Third, although we used a grid developed from prior studies, the coding ultimately involves some subjectivity. Fortunately, we used a modified Delphi approach and two independent coders to code the data in our data coding process. We found a high degree of similarity in our results. Future research may add a hold-out group to code the data again and compare the results. Thus, this additional step will further lower the subjective bias. Last, interview data may contain recall bias (Eisenhardt \& Graebner, 2007). To deal with this issue, we asked all of the deal evaluators (one E.D. and three members of E.C.) to provide their thoughts on each deal. We then cross-validated the interviews to reduce the recall bias and caught complementary information a single informant could miss.

\section{Conclusion}

Overall, we agree with Petty \& Gruber's (2011: 185) insights "that many of the deals categorized as dead were the result of action by the company rather than rejection by the VC should provide evidence that the world of VC is both a buyer's and a seller's market." Based on our study, the reasons small deals are not done have to do with both the buyer and the seller. Those businesses rejected by G.F. may have had the right valuation and great potential, but the G.F. simply was not the correct buyer. That should encourage rural entrepreneurs not to obsess over failed deals. Alternatively, the seller may have had unrealistic financial expectations or behaved in a manner that became odious to the prospective buyer. These are deal-killers under the control of rural entrepreneurs aspiring to sell their businesses. 


\section{REFERENCES}

Ahlers, O., Hack, A., Kellermanns, F., \& Wright, M. (2016). Opening the black box: Power in buyout negotiations and the moderating role of private equity specialization. Journal of Small Business Management, 54(4), 1171-1192. https://doi.org/10.11 $\underline{11 / \text { jsbm. } 12235}$

Anderson, S., Prokop, K., \& Kalpan, R. S. (2007). Fasttrack profit models: More powerful due-diligence process for mergers and acquisitions. The Journal of Private Equity, 10(3), 22-34. https://doi.org/10.3905/i pe.2007.686427

Astrachan, J. H., \& Jaskiewicz, P. (2008). Emotional returns and emotional costs in privately held family businesses: Advancing traditional business valuation. Family Business Review, 21(2), 139-149. https://doi.or g/10.1111/j.1741-6248.2008.00115.x

Bansal, P., Smith, W., \& Vaara, E. (2018). New ways of seeing through qualitative research. Academy of Management Journal, 61(4), 1189-1195. https://doi.or g/10.5465/amj.2018.4004

Baum, J., Li, S., \& Usher, J. (2000). Making the next move: How experiential and vicarious learning shape the locations of chains' acquisitions. Administrative Science Quarterly, 45, 766-801.

Bruce, D., \& Picard, D. (2006). Making succession a success: Perspectives from Canadian small and medium - sized enterprises. Journal of Small Business Management, 44(2), 306-309. https://doi.org/10.1111/ j.1540-627x.2006.00171.x

Cannella, A., \& Hambrick, D. (1993). Effects of executive departures on the performance of acquired firms. Strategic Management Journal, 14(S1), 137-152. http s://doi.org/10.1002/smj.4250140911

Carpentier, C., \& Suret, J. M. (2015). Angel group members' decision process and rejection criteria: A longitudinal analysis. Journal of Business Venturing, 30(6), 808-821. https://doi.org/10.1016/j.jbusvent.20 $\underline{15.04 .002}$

Chakrabarti, A., \& Mitchell, W. (2016). The role of geographic distance in completing related acquisitions: Evidence from U.S. chemical manufacturers. Strategic Management Journal, 37(4), 673-694.

Croce, A., Tenca, F., \& Ughetto, E. (2017). How business angel groups work: Rejection criteria in investment evaluation. International Small Business Journal, 35(4), 405-426. https://doi.org/10.1177/0266242615622675

Davidsson, P., \& Honig, B. (2003). The role of social and human capital among nascent entrepreneurs. Journal of Business Venturing, 18(3), 301-331. https://doi.org/ 10.1016/s0883-9026(02)00097-6

Dawson, A. (2011). Private equity investment decisions in family firms: The role of human resources and agency costs. Journal of Business Venturing, 26(2), 189-199. https://doi.org/10.1016/j.jbusvent.2009.05.0 $\underline{04}$
Dawson, A., \& Barrédy, C. (2018). Private equity investment in family firms: the role of stake size and deal syndication. Venture Capital, 20(4), 355-376. htt ps://doi.org/10.1080/13691066.2018.1516358

De Massis, A., Chua, J. H., \& Chrisman, J. J. (2008). Factors preventing intra - family succession. Family Business Review, 21(2), 183-199. https://doi.org/10.11 11/j.1741-6248.2008.00118.x

Eisenhardt, K., \& Graebner, M. (2007). Theory building from cases: Opportunities and challenges. Academy of Management Journal, 50(1), 25-32. https://doi.org/1 0.5465/amj.2007.24160888

Engel, Y., van Werven, R., \& Keizer, A. (2020). How novice and experienced entrepreneurs name new ventures. Journal of Small Business Management, 1-31. https://doi.org/10.1080/00472778.2020.1738820

Ferrati, F., \& Muffatto, M. (2021). Reviewing equity investors' funding criteria: a comprehensive classification and research agenda. Venture Capital, 23(2), 157-178. https://doi.org/10.1080/13691066.202 1.1883211

Gómez-Mejía, L. R., Haynes, K. T., Núñez-Nickel, M., Jacobson, K. J., \& Moyano-Fuentes, J. (2007). Socioemotional wealth and business risks in familycontrolled firms: Evidence from Spanish olive oil mills. Administrative Science Quarterly, 52(1), 106-137. https://doi.org/10.2189/asqu.52.1.106

Graebner, M., \& Eisenhardt, K. (2004). The seller's side of the story: Acquisition as courtship and governance as syndicate in entrepreneurial firms. Administrative Science Quarterly, 49, 366-403.

Granz, C., Henn, M., \& Lutz, E. (2020). Research on Venture Capitalists' and Business Angels' Investment Criteria: A Systematic Literature Review. Contemporary Developments in Entrepreneurial Finance, 105-136. https://doi.org/10.1007/978-3-03 0-17612-9 5

Harrison, R. T., Mason, C., \& Smith, D. (2015). Heuristics, learning and the business angel investment decision-making process.

Entrepreneurship \& Regional Development, 27(9-10), 527-554. https://doi.org/10.1080/08985626.2015.106 $\underline{6875}$

Kim, E. H., \& Singal, V. (1993). Mergers and market power: Evidence from the airline industry. The American Economic Review, 83(3), 549-569.

King, D. R., Meglio, O., Gomez - Mejia, L., Bauer, F., \& De Massis, A. (forthcoming). Family Business Restructuring: A Review and Research Agenda. Journal of Management Studies.

Leibell, D. T. (2015). Selling the family business. Trusts \& Estates, 25-28.

Leroy, H., Manigart, S., Meuleman, M., \& Collewaert, V. (2015). Understanding the continuation of firm activities when entrepreneurs exit their firms: Using theory of planned behavior. Journal of Small Business Management, 53(2), 400-415. https://doi.org/10.1111/ jsbm.12077 
Lumpkin, G. T., Brigham, K. H., \& Moss, T. W. (2010). Long-term orientation: Implications for the entrepreneurial orientation and performance of family businesses. Entrepreneurship \& Regional Development, 22(3-4), 241-264. https://doi.org/10.10 $\underline{80 / 08985621003726218}$

Mason, C., \& Botelho, T. (2016). The role of the exit in the initial screening of investment opportunities: The case of business angel syndicate gatekeepers.

International Small Business Journal, 34(2), 157-175. $\underline{\mathrm{h}}$ ttps://doi.org/10.1177/0266242614563419

Mason, C., Botelho, T., \& Harrison, R. (2019). The changing nature of angel investing: some research implications. Venture Capital, 21(2-3), 177-194. http s://doi.org/10.1080/13691066.2019.1612921

Mason, C., Botelho, T., \& Zygmunt, J. (2017). Why business angels reject investment opportunities: Is it personal?. International Small Business Journal, 35(5), 519-534. https://doi.org/10.1177/0266242616646622

Maxwell, A. L., Jeffrey, S. A., \& Lévesque, M. (2011). Business angel early stage decision making. Journal of Business Venturing, 26(2), 212-225. https://doi.org/1 0.1016/j.jbusvent.2009.09.002

Moore Jr, R. B., Floyd, P. H., \& Korabik, R. M. (1995). M\&A for smaller companies. Journal of Accountancy, 180(5), 71-74.

Muehlfeld, K., Rao Sahib, P., \& Van Witteloostuijn, A. (2012). A contextual theory of organizational learning from failures and successes: A study of acquisition completion in the global newspaper industry, 1981-2008. Strategic Management Journal, 33(8), 938-964. https://doi.org/10.1002/smj.1954

Murray, A., Kotha, S., \& Fisher, G. (2020). Communitybased resource mobilization: How entrepreneurs acquire resources from distributed non-professionals via crowdfunding. Organization Science, 31(4), 960-989. https://doi.org/10.1287/orsc.2019.1339

Ott, T. E., \& Eisenhardt, K. M. (2020). Decision weaving: Forming novel, complex strategy in entrepreneurial settings. Strategic Management Journal, 41(12), 2275-2314. https://doi.org/10.1002/smj.3189

Petty, J. S., \& Gruber, M. (2011). "In pursuit of the real deal”: A longitudinal study of VC decision making. Journal of Business Venturing, 26(2), 172-188. http s://doi.org/10.1016/j.jbusvent.2009.07.002

Scholes, M. L., Wright, M., Westhead, P., Burrows, A., \& Bruining, H. (2007). Information sharing, price negotiation and management buy-outs of private family-owned firms. Small Business Economics, 29(3), 329-349. https://doi.org/10.1007/s11187-006-9024-z
Shen, J., \& Reuer, J. (2005). Adverse selection in acquisitions of small manufacturing firms: A comparison of private and public targets. Small Business Economics, 24(4), 393-407. https://doi.org/1 0.1007/s11187-005-5332-y

Singh, S., Corner, P. D., \& Pavlovich, K. (2015). Failed, not finished: A narrative approach to understanding venture failure stigmatization. Journal of Business Venturing, 30(1), 150-166. https://doi.org/10.1016/j.jb usvent.2014.07.005

Sinyard, D. B., Dionne, S. S., \& Loch, K. D. (2020). Fast thinking in private equity: The role of heuristics in screening buyout opportunities. Journal of Small Business Management, 58(6), 1221-1255. https://doi.o rg/10.1111/jsbm.12451

Slee, R. (2009). The new math of middle market M\&A. The Value Examiner, July/August, 13-15.

Thornton, P. (2001). Personal versus market logics of control: A historically contingent theory of the risk of acquisition. Organization Science, 12(3), 294-311. http s://doi.org/10.1287/orsc.12.3.294.10100

Wang, L., \& Zajac, E. (2007). Alliance or acquisition? A dyadic perspective on interfirm resource combinations. Strategic Management Journal, 28(13), 1291-1317. https://doi.org/10.1002/smj.638

Wong, P., \& O’Sullivan, N. (2001). The determinants and consequences of abandoned takeovers. Journal of Economic Surveys, 15(2), 145-186. https://doi.org/10.1 111/1467-6419.00135

Worek, M. (2017). Mergers and acquisitions in family businesses: current literature and future insights. Journal of Family Business Management, 7(2), 177-206. https://doi.org/10.1108/ifbm-04-2016-0009

Wright, M., Gilligan, J., \& Amess, K. (2009). The economic impact of private equity: what we know and what we would like to know. Venture Capital, 11(1), 1-21. https://doi.org/10.1080/13691060802151887

Wright, P., Kroll, M., Lado, A., \& van Ness, B. (2002). The structure of ownership and corporate acquisition strategies. Strategic Management Journal, 23(1), 41-53. https://doi.org/10.1002/smi.208

Yu, A., Lumpkin, G. T., Sorenson, R. L., \& Brigham, K. H. (2012). The landscape of family business outcomes: A summary and numerical taxonomy of dependent variables. Family Business Review, 25(1), 33-57. http s://doi.org/10.1177/0894486511430329

Yu, L., \& Artz, G. (2019). Does rural entrepreneurship pay? Small Business Economics, 53(3), 647-668. http s://doi.org/10.1007/s11187-018-0073-X 